\title{
ANTI-RACIST PEDAGOGY AND THE CANONIZATION OF TONI MORRISON
}

\author{
Dr. Min Pun (Nepal)
}

\begin{abstract}
The paper aims to examine the anti-racist approach in pedagogy in relation to the issues of representations of African Americans in American schools, curricula, and literary canon. It has considered anti-racist pedagogy as a correct approach to creating a truly democratic society in a racist society like the United States of America. In order to address these issues, Toni Morrison has been considered the most successful African American writer who has attained canonical status within the mainstream of both African American and American literature. The paper has, thus, raised some of the vital issues related to the representations of African Americans in American schools, curricula, and the literary canons.
\end{abstract}

KEYWORDS: Anti-racist education; anti-racist pedagogy; American canon; African Americans; Toni Morrison

\section{INTRODUCTION}

In this paper, the focus is on the issues of representations of African Americans in American schools, curricula, and literary canon. Interestingly, the continuity and change in the canon are intimately connected with the pedagogy of language and literature teaching. With the efforts of African American intellectual generations, some of the African American literary works, including some slave narratives, have now been chosen for language and literature teaching at different educational levels and at different periods of history.

In principle, democratic education in a racist society requires anti-racist pedagogy. It improves the confidence of students and teachers, contributing to their sense of purpose for being at schools. In effect, some teaching strategies are better suited to certain student backgrounds, learning styles and abilities. Traditionally, the approaches to democratic education conceive racism in terms of personal prejudice and do not address problems that racism actually poses. But anti-racist pedagogy offers a critique of analytic connections between race and education within the context of an African American struggle for humanity. In particular, anti-racist pedagogy has functioned as a discourse on schooling and inequality that has developed in parallel with theories of race and pedagogical practice in the ways that reflect the context of African American education.

The debate about anti-racist education continues as a society like the United States adjusts to a multicultural context. The spread of multicultural context in parallel continues to be resisted by the dominant cultural groups such as the 


\section{Crossing the Border: International Journal of Interdisciplinary Studies}

European American cultural traditions. Because the advocates of ethnocentric education for dominant cultures envision the continuing importance of the European and European American cultural traditions in the canons and pedagogy of the country. Thus, as Morrison's novels protest, the educators need to avoid racist and sexist behavior and to know how to teach anti-racist and anti-sexist attitudes in the American educational institutions.

\section{ANTI-RACIST APPROACH IN PEDAGOGY}

The debates at present regarding anti-racist education take up a number of themes that Alain Locke (1974) considers in his arguments on behalf of art versus propaganda ("Art", p. 312). Here, the pedagogical goals and methods of several models of anti-racist education have been discussed. The first example includes models for anti-racist education as an art. Another example is anti-racist education, which is designed to maintain and restore a dominated culture by using education as propaganda.

To many critics, anti-racist pedagogy has all earmarks of propaganda. Certainly, the popular media portrays "anti-racist and other progressive pedagogies as extremist, humorless, strident, and biased" (Locke, 1989, "Values", p. 47). The catch phrase "politically correct" has become shorthand for an ideologically mandated equality that violates a common sense. To its advocates, on the other hand, antioppressive pedagogy represents an important chance to help the marginalized students flourish and to engage the privileged students in knowledge-seeking that sets aside assumptions, allowing them to accept or dismiss alternative perspectives.

In what follows is to examine Alain Locke's art/propaganda framework with regard to its implications for the latter-day efforts to help end the white/Black racism through public education. In this connection, Audrey Thompson (1997) argues that anti-racist pedagogy is specifically tied to schooling, but the art/ propaganda framework shares in "some of the grand ambitions of the Harlem Renaissance with regard to the possibility of fostering genuinely egalitarian appreciation and conversation between Black and white Americans" (p. 19). The commentators of the period differed as to whether the African American artists should make a point of depicting the blacks in a positive light, but the movement was clearly attuned to educational considerations.

Pedagogy that identifies the "traditional knowledge as andro-, hetero-, or Eurocentric, for example, is said to substitute an anti-male, anti-straight, or antiwhite or, more simply, anti-American approved version of history or literature, for objective standards that define Western knowledge" (Thompson, 1997, p. 20). From this perspective, the claims made on behalf of anti-racist or anti-sexist canons and pedagogy are unwarranted. Indeed, the hollowness of the claims is said to be evidenced by their facile substitution of what their proponents would like everyone to believe for what ordinary people and experts actually believe. The only warrant offered for such claims, a critic like Audrey Thompson (1997) contends, is their "political correctness" (p. 23), that is, their agreement with a particular ideological agenda.

The main concern here is with propaganda in an almost academic sense, as reaction or correction. Such propaganda needs not be undiscriminating, it may be minutely discriminating, concerned with the most subtle nuances of 
understanding. Many well-intentioned corrections to textbooks are propagandist in this sense insofar as they seek to adjust imbalances, correct misperceptions, increase minority representation, or dispel myths. The trouble with such educational strategies, as Locke (1968) points out, is that they "invoke the very assumptions they are intended to discredit" ("The Legacy", p. 233). Because they take the form of amendments to an otherwise fixed framework, the effect is likely to appear disproportionate, even monstrous. If the whiteness is assumed as a norm, any appeal to specifically black issues, historical figures, or points of view leaps out as a radical departure from supposedly neutral standards that govern the basic textbook narrative.

At least, two educational perspectives suggest that anti-racist pedagogy is propagandist in Locke's sense of the term. From one perspective, an anti-racist approach seems to exaggerate or otherwise distort problems that racism poses for knowledge in a democracy (Thompson, 1997, p. 17). Since liberal education seeks to dismantle all forms of bias by directing the attention outward, towards the general and the universal and away from the merely idiosyncratic, knowledge or value claims explicitly referenced to a minority group or, indeed, any identifiable group is considered problematic because they are particularistic.

A second, related objection is that anti-anything approaches to education start off on the wrong foot. The point is not only those approaches adopt a negative tone. But Alain Locke argued that they have no independent vision of the good. They are also defined by what is wrong with education as it stands and not by what education ought to look like. From the perspective of Afrocentrism, anti-racist pedagogy is reactive. What is needed is a race-centered education of a kind that takes up the issues of race in the context of a shared cultural heritage or a shared economic future rather than a shared political problem. Here, the argument that "anti-racism is a political category to be decided upon, an emergent standard and not a fixed point of reference, does raise an important challenge to Locke's notion of art as capable in itself of supplying anti-racist truth" (as cited in Thompson, 1997, p. 41). Yet to use the argument to discredit the very concept of pedagogy referenced to political concerns would be to undercut the appeal to an emergent approach to democratic education.

The power relations are woven into the fabric of human lives, goals, and values; they are not possible to start with politics. Rather conceiving of anti-racist pedagogy as a blueprint for righteous teaching is one of the projects of teaching. One of the concrete questions that democracy has to do today is that of how to overcome racism, a question that pedagogy cannot afford to ignore.

Thus, anti-racist pedagogy is not inherently propagandist. Of course, this is not at all to say that it is not, in particular cases. As Alain Locke (1989) notes,

Insofar as education is conceived in terms of texts and curricula that have racist attitudes and assumptions, it is conceived as a form of propaganda.

But of course texts and curricula are not magical repositories of anti-racism that can, of themselves, transform racist sentiments, ideology, or structural relations. ("Values", p. 50)

So the role that education can play in addressing racism lies less in restricting to particular texts, methods, or lessons than in developing a pedagogy that actively takes up the race relations as a key element of inquiry. Like art, pedagogy can 


\section{Crossing the Border: International Journal of Interdisciplinary Studies}

create spaces in which the ordinary, everyday meanings to experience are revisited as if it is self-evident.

\section{ART/PROPAGANDA DICHOTOMY IN PEDAGOGY}

A key to Alain Locke's notion of art as education is its avoidance of argumentation. For him, the problem posed by propaganda is not that it serves a particular agenda. Obviously, he meant for art to serve "a distinct social, political, and intellectual agenda" (1974, "Art", 314). Thus, unlike the more familiar opposition between propaganda and common sense, or between propaganda and open inquiry, Alain Locke's art/propaganda dichotomy suggests that the most important obstacle to social understanding may be a form of literal-mindedness: accepting some starting points as a given and seeking a change through incremental adjustments.

In effect, then, Alain Locke rejects the kind of approach to promoting an interracial understanding taken by liberal education. In the traditional liberal arts model, as Gloria Ladson-Billings (1994) argues, "the path to a freer understanding is through careful analysis, reasoned argumentation, and dialogue" (p. 231). But for Alain Locke this approach reintroduces the very assumptions that preclude a transformed understanding. Particularly, in the case of black/white relations, what is called for is the reorientation in thinking rather than the correction of each and every error in the existing understandings. As a pragmatist, Locke saw a change not in terms of incremental improvement but in terms of shifts, adopting new positions and entering into new relations.

The question considered here is the extent to which Alain Locke's art/ propaganda framework is useful for categorizing the workings of anti-racist pedagogy. His distinction between art and propaganda offers "a way to frame anti-racist pedagogy in terms other than those of liberal education, while still embracing democratic relations and intellectual understanding as central goals of education" (1974, "Art", p. 317). As a tool, it serves a crucial purpose in highlighting the need for anti-racist education to step outside the premises of racism. His dichotomy lends itself to an essentialized conception both of race and truth. However, it falls short of an emergent approach to pedagogy that is called for by anti-racist agenda for education. His approach is followed by an aesthetic metaphor for anti-racist education. But in order to address some of the limitations of Locke's art/propaganda dualism is for a conception of anti-racist pedagogy.

Whereas propaganda, in Alain Locke's formulation, refers to an emendatory impulse, art refers to the development of new perspectives. The importance of art lies in its refusal to read the social convention literally. As a metaphor for anti-racist education, it means, in part, "problematizing the supposedly neutral standards that privilege whiteness, and, in part, re-conceiving both whiteness and Blackness" (1968, "The Legacy", p. 335). In invoking art as opposite of propaganda, He grants much to art. By holding on to enlightenment assumptions about the truth, he proposes a misleading role for art as somehow apolitical in contrast to propaganda as inherently ideological.

The romantic strain in Alain Locke's conception of art is revealed in his belief that "the art of the people," specifically peoples of African ancestry, is "a tap root of vigorous, flourishing living" (1968, "Art" p. 313). Such art, he believed, is the 
source of a beauty that reveals the truth, for unlike academic art, it has not been subjected to the "generations of the inbreeding of style and idiom" (1968, "The Legacy", p. 258), nor lost the capacity to see objectively. The Negro physiognomy must be freshly and objectively conceived on its own patterns if it is ever to be seriously and importantly interpreted. Art must discover and reveal the beauty which prejudice and caricature have overlaid (Locke, 1968, “The Legacy”, p. 264).

Art, as Alain Locke (1968) believed, offered a way to break with old stereotypes and invent many new forms, while remaining true to "some sort of characteristic idiom" ("The Legacy", p. 267). It is a distinctive heritage and expressive style. The pragmatist that he was, he saw art as a way to come to the experience both with a fresh eye and with an experience of the rich ancestral legacy.

But Alain Locke's account differs from that of John Dewey in emphasizing the autonomy of feeling. For Locke, the feeling has a distinctive claim to value and truth. Critiquing Dewey's logico-experimental approach to inquiry, Locke (1989) observed that truth is not only "the correct anticipation of experience," but it may be as well the sustaining of an attitude, the satisfaction of a way of feeling, and the corroboration of a value. To the poet, beauty is truth; to the religious devotee, God is truth; and to the enthused moralist, what ought-to-be overtops factual reality ("Values", p. 37). So art allows for the perception of the truths beyond the perceived facts, and in Locke's view, therefore, offers a representation of experience at once more objective, more inclusive, and more stirring than conventional, everyday language could allow for. Art, in short, can be "a profound and galvanizing influence" (1968, "The Legacy", p. 256), at once a symbol of and a vehicle for the new. The power of art to teach is in part a matter of teaching how to see, how to respond, and how to appreciate. The artist, framing experience in fresh ways, teaches the reader or viewer to see possibilities, relations, and beauty previously not apparent. Yet the artist is less a visionary than a naturalist, someone who observes the nature objectively, on its own terms. While he is particularly drawn to possibilities of an abstract art and clearly does not think of objectivity in terms of anything like a transcription of reality, he does regard art as representing an experience in more direct, expressive ways than are possible through everyday language. In particular, for the African Americans, the prejudicial imagery and the orderings of what is called a common sense serve as a constant source of misrepresentation.

The difficulty with Alain Locke's conception of art, as Audrey Thompson (1997) argues, is that it appears to have "an essentialist though also pluralist conception of beauty and truth, as if what art does is to strip away the sedimented accumulation of prejudice, convention, and convenient stereotypes, thereby revealing the underlying experience" (p. 19). This view of art as both from what he says about the triumph of beauty and truth and from his characterization of art as opposite of propaganda. On this view, propaganda is partial, reactive, and political in the sense of partisan. Art, by contrast, is whole, active, authentic, and implicitly above politics.

Thus, the art/propaganda dichotomy assumes that "art simply expresses experience or a vision without political overtones; by contrast, propaganda is instrumental and reduces vision to editing" (Thompson 31). But art, like its counterpart in pedagogy, involves selecting a form and reworking an experience, framing it for an audience. Since the experience of blackness and whiteness in society is inherently political, art in terms of race cannot escape politics. 


\section{Crossing the Border: International Journal of Interdisciplinary Studies}

\section{ANTI-RACIST EDUCATION AS DEMOCRATIC}

Anti-racist education is a democratic approach to address the issues of representations of African Americans in the United States through education.Yet neither can it treat the classroom as an innocent space in which to avoid racism, as if anti-racist education consisted in "not giving children ideas," rather like some versions of sex education (Locke, 1968, "The Legacy", p. 256). In this sense, antiracist pedagogy is both personal and political. Adrienne Rich (1993) speaks to the need to become the kind of person who can read a poem (p. 43); anti-racist pedagogy asks to become a kind of person who can respond to racial possibilities. If politics is regarded, at its best, as a vital engagement over how to structure the possibility for democratic relations, anti-racist pedagogy offers a tool for the rethinking of democracy.

On the other hand, Gloria Ladson-Billings (1994) describes anti-racist teaching as "a pedagogy that empowers students intellectually, socially, emotionally, and politically by using cultural referents to impart knowledge, skills, and attitudes" (pp. 17-18). Ladson-Billings also criticizes the assimilationist approach to teaching: teaching students to fit into "one American identity" (p. 34). Similarly, Jenice E. Hale-Benson (1982) argues that traditional education in the United States was designed for the middle-class European American children (p. 65). As a result, Hale-Benson urges the educators to seek out some ways to avoid trying to adapt the black children so that they fit into an educational system that is not designed for them. Together, the advocates of anti-racist pedagogy suggest that the educators change the system itself so that it is more accommodating to blacks, poor whites, and other marginalized groups of students.

Another component common with anti-racist pedagogy is its insistence upon the text selection that seeks to provide the students with an exposure to the books about the people of various cultures. Arthur N. Applebee's 1993 study supports the notion that there is an absence of black presence as well as the presence of most people of color in the English curriculum in public schools. He describes the results of that study as follows: "Our examination of the selections chosen for study creates a picture of a curriculum dominated by familiar selections drawn primarily from a white, male, Anglo-Saxon tradition" (p. 82). However, Paul Lauter (1991) argues that "the problem of changing curriculum has primarily to do with learning to understand, appreciate, and teach about many varied cultural traditions" (p. 108). Since the critical race theorists believe that racism is a normal, but often unrecognizable, part of human lives, it would be easy to ignore ingrained racism that influences the selection of texts that is used in the classroom.

When studying the literature anthologies, Arthur N. Applebee (1993) also found that American literature anthologies were contributing more multicultural literature. However, there is still little attention given to diverse literature and literature by women and multicultural groups is lumped under one heading, "the twentieth century" as he says, "It is hard to imagine that the handful of selections by African American, Hispanic, Asian, or Native American authors, for example, is sufficient to leave students with a unique sense of the substance and appeal of these alternative traditions, but neither are these traditions well-integrated into a larger, common tradition" (p. 115). Applebee's study, here, indicates that there are some aspects of public schooling that maintain the subordination of students of color and the status quo. 
Linda A. Spears-Bunton \& Carol D. Lee's studies further expose the white privilege while simultaneously serving as examples of culturally relevant teaching. Both researchers reveal that they deliberately chose to use African American literature because it was not traditionally used in the public school classroom. For example, Spears-Bunton (1990) reports that the teacher in her study was unhappy with the "version" of American literature in her anthology, and, as a result, she decided to include African American literature in her classroom. She states that the teacher "opened herself up to criticism from administrators and colleagues" (p. 568) because she was the first to teach black literature in her classroom. It is also important to note that the students requested that the teacher include black literature because they too noticed the void in the curriculum.

Carol D. Lee's study of 1993 points out the importance of bringing black literature to the "forefront of research" and the classroom focus because "Traditionally, research in the teaching of literature very rarely focuses on literary texts by authors who are not white and male" (p. 134). She mentions that the black literature texts used in her study are not "part of the traditional storage of books that English departments have on hand" (p. 139). Her study validates the black students' experiences while expressing a concern for illiteracy amongst the black students. As Spears-Bunton struggles with whether culture has an influence on, Carol D. Lee (1993) ponders how "culture affects comprehension of literature" (p. 32). She is concerned with signifying, a form of social discourse in the African American community, and how it might be used as a scaffold to teach the students certain interpretive strategies for a literary analysis. She explains, "I propose that novice African American adolescent readers bring into classrooms a powerful intellectual tool [signifying] which goes unnoticed, devalued, and untapped" (p. 13). Thus, in reconstructing American literature, it is necessary to precisely place the study of all cultures for equal and fulfilling education.

The culturally relevant teaching presented in Carol D. Lee and Sears-Bunton's studies support the notions of anti-racist pedagogy which advocate challenging the idea that white people's experiences are the normative standard. They argue that utilizing a European world view to think critically about literature by and about the people of color is problematic. Nobel laureate Morrison (1984) writes, in this regard,

I don't like to find my books condemned [...] or praised [...] when that condemnation or ... praise is based on criteria from other paradigms. I would much prefer that [my books] were dismissed or embraced based on the success of their accomplishment within the culture out of which I write. ("Rootedness", p. 342)

Many scholars suggest that allowing the students an opportunity to read literature about the people of color is important, but teaching those students to employ culturally specific lenses when analyzing a literary text is equally important.

\section{TONI MORRISON AS THE CENTER OF THE CANON}

The writings of African Americans are about the lives of people in the United States, which is "highly and historically racialized society" (Morrison, 1992, Playing, p. 4). As Morrison notes in her own study of what racial ideology does to the mind and imagination of masters, it should be acknowledged that 


\section{Crossing the Border: International Journal of Interdisciplinary Studies}

Just as the formation of the nation necessitated coded language and purposeful restriction to deal with racial disingenuousness and moral frailty at its heart, so too did the literature, whose founding characteristics extend into the twentieth century, reproduce the necessity for codes and restriction. (Playing, p. 6)

Morrison states bluntly and authoritatively, for both the black and white American writers, in a wholly racialized society, there is no escape from the racially inflected language. Thus, living as an African American in "a racially articulated and predicated world" (Playing, pp. 15-16), it is necessary to take care of the things carefully, whether there is racism or not.

The point is that it cannot be taken for granted that art or propaganda would automatically shift the African Americans to a new place in racial relations. It can easily entrench racism or worsen it. The potential of art must be distinguished from the success of any given performance and always be remained mindful of its dangers. Propaganda itself, whether pedagogical or not, would not necessarily be free of racism. Likewise, art itself is not necessarily free of racism.

As such, as Justine Tally (2007) notes, it is inappropriate to define Morrison as "marginal," not because she has moved to "the center of the canon, but because she has managed to move the center" (p. 1). For Harold Bloom (2007), Morrison and her works are "central to the current canon of literature read and studied in American schools and colleges" (p. 8). In fact, it would be more appropriate to say that because of her multi-faceted and untiring work, she has helped change a restricted, predominantly white, and male-centered literary world into a multicultural society. Interestingly, it is also not easy for her to attain that canonization which is seldom granted to women writers, almost never to the blacks. A debate about the canon is connected with important recent debates concerning interpretations and representations of African Americans in the mainstream of American life. Morrison plumped out with interpretations of the critics and in fact attained her canonical status, representing her race and culture. She is yet the first non-white, non-male African American woman writer to challenge the hegemony of the white and male center. She herself is alert to the ways in which the blacks' and women's writing have been patronized and excluded from the mainstream. After winning the Noble Prize in 1993, as Susanna Rustin (2008) says, Morrison wrote that she felt she had earned a "licence to strut" (Online). With her entry into the world of interpretations and the African American literary pedagogy, Morrison exercises power over the literary discourse of African American presence in the mainstream American life.

In addition, in context, Morrison's canonical status as an African American writer has also been both political and collective in nature. For example, in 1987, a group of forty-eight black writers wrote an open letter to the New York Times, decrying the non-recognition of her Beloved for both the American Book Award and the Pulitzer Prize. Eventually, she has been canonized as great, and whose works, irrespective of her base in the marginalized discourse in terms of race, gender and color, have been widely studied and taught in schools and universities around the world.

It is ant-racist education that must be for an ethnically and culturally sustained pluralist society that is arguably most appropriate in the context of American 
ethnic diversity. In an interview, on a question for improving the present-day climate in America, Morrison (1989) replies, "It is a question of education, because racism is a scholarly pursuit. It's all over the world, I am convinced. But that's not the way people were born to live. I'm talking about racism that is taught, institutionalized. Everybody remembers the first time they were taught that part of the human race was Other" ("The Pain", p. 49). Here, as a critic, Morrison refuses to allow race to be marginalized in American literary pedagogy. Rather those texts which are in the margin should be considered for artistic or cultural point of view. For example, she focuses on the importance of the African American's oral and musical culture and reclaims black historical experiences.

The African Americans have rediscovered texts that have long been suppressed or ignored, have sought to make places for African American literature within the canon, and have developed ways of interpreting these works. For example, Morrison's international appeal increased dramatically, following the awards of Pulitzer Prize and Nobel Prize, as Deirdre J. Raynor \& Johnnella E. Butler (2007) add: “Toni Morrison's work within anti-racist and human rights organizations seems to be a natural extension of her project as a writer, and to complement her "speakerly" texts rooted in history and experience, inviting reflection on the present" (p. 182). For Morrison, in the conception of Alain Locke's pedagogy as an art, anti-racist education is most likely both to receive sustained public support in the liberal democratic society and retain the essential capacity to evolve in relation to needs and aspirations of all Americans.

\section{CONCLUSION}

To conclude, the main concern here is not in all forms of anti-racist activity, but on anti-racist education, particularly anti-racist pedagogy. It means that antiracist pedagogy is profoundly educative and not simply politics by other means. Because different teaching strategies used in different situations with different groupings of students will improve learning outcomes. For example, through her novels, Morrison envisions a future where the people of color, especially the African Americans, in the context of American education, achieve their equality of political, economic, and cultural power. In principle, the canons impose a needed sense of order for pedagogical purposes. For example, teaching African American literature offers the teachers new methods to bring the distinguished tradition of African American literature into their classrooms.

\section{REFERENCES}

Applebee, Arthur N. (1993). Literature in the secondary school: Studies of curriculum and instruction in the United States. Illinois: NCTE.

Bloom, Harold. (2007). Introduction. In Harold Bloom (Ed.), Toni Morrison's Beloved (First Indian Edition, pp. 1-3). New Delhi: Viva Books.

Dewey, John. (1987). Education and social change. In Kathleen E. Poulos et.al., The Later Works 1935-1937 (Vol. 11, p. 417). Carbondale: Southern Illinois University Press.

Hale-Benson, Jenice E. (1982). Black children: Their roots, culture, and learning styles. Baltimore: Johns Hopkins University Press.

Ladson-Billings, Gloria. (1994). Dreamkeepers: Successful teachers of African 


\section{Crossing the Border: International Journal of Interdisciplinary Studies}

American children. San Francisco: Jossey-Bass Publishers.

Lauter, Paul. (1991). Canons and contexts. New York: Oxford.

Lee, Carol D. (1993). Signifying as a scaffold for literary interpretation: The pedagogical implications of an African American discourse genre. Illinois: NCTE.

Locke, Alain. (1974). Art or propaganda? In Nathan Irvin Huggins (Ed.), Voices from the Harlem Renaissance (pp. 310-323). New York: Oxford University Press.

Locke, Alain. (1968). The legacy of the ancestral arts. In Alain Locke (Ed.), The New Negro: An Interpretation (pp. 232-235). New York: Arno Press.

Locke, Alain. (1989). Values and imperatives. In Leonard Harris (Ed.), The Philosophy of Alain Locke: Harlem Renaissance and Beyond (pp. 22-67). Philadelphia: Temple University Press.

Morrison, Toni. (1989, May 22). The pain of being black. By Bonnie Angelo. Time, 48-50.

Morrison, Toni. (1992). Playing in the dark: Whiteness and the literary imagination. Cambridge, Massachusetts, and London: Harvard University Press.

Morrison, Toni. (1984). Rootedness: The ancestor as foundation. In M. Evans (Ed.), Black Women Writers (1950-1980): A Critical Evaluation (pp. 339-345). New York: Anchor Press.

Raynor, Deirdre J. \& Johnnella E. Butler. (2007). Morrison and the critical community. In Justine Tally (Ed.), Cambridge Companion to Toni Morrison (pp. 175-183). Cambridge: Cambridge University Press.

Rich, Adrienne. (1993). What is found there: Notebooks on poetry and politics. New York: W. W. Norton.

Rustin, Susanna. (2008, November 1). Predicting the past. The Guardian. Retrieved 21 May 2009 from <http://www.guardian.co.uk/books/2008/nov/01/tonimorrison>.

Spears-Bunton, Linda A. (1990). Welcome to my house: African American and European American students' responses to Virginia Hamilton's house of dies drear. Journal of Negro Education, 59(4), 566-576.

Tally, Justine. (2007). Introduction: 'All necks are on the line.' In Justine Tally (Ed.), Cambridge Companion to Toni Morrison (pp. 1-7). Cambridge: Cambridge University Press.

Thompson, Audrey. (1997, Spring). For: Anti-racist education. Curriculum Inquiry, 27(1), 7-44.

\section{ABOUT THE AUTHOR}

Dr. Min Pun is Associate Professor of English at Tribhuvan University, Prithvi Narayan Campus, Pokhara. He received his Ph.D. from Tribhuvan University and had been a Visiting Researcher at the University of Tokyo, Japan from 2003 to 2005. He has authored a series of textbooks in English course entitled "Focus English" for private schools in Nepal. Recently, he has also authored a series of optional English courses entitled "Developing Your English” for community schools in Nepal. Email: minpun@pncampus.edu.np 